\title{
Mycobiota features of aphyllophorales mushrooms in arid conditions of the south-east Euroopean Russia
}

\author{
Nadezhda Kuragina * \\ Volgograd State University, Departament of biology, 400062, Universitetsky Ave., 100, Volgograd, \\ Russia
}

\begin{abstract}
An analysis of the biota of the aphyllophorales mushrooms carried out in the territory of the Volga-Akhtuba floodplain natural park within the Volgograd region. Based on the results of the conducted researches, 170 species of the study group are noted in the park. The great majority of identified species are saprotrophs on dead fallen wood. The largest number of species was found on Quercus robur, Populus alba, P. nigra и Fraxinus lanceolata. The largest number mushrooms ecological groups for moisture are mesophiles and xerophiles, which is typical for the arid zone.
\end{abstract}

\section{Introduction}

The natural park «Volga-Akhtuba floodplain» is located between the Volga River and its sleeve Akhtuba, representing the vegetation islet in the middle of plain zone. There are azonal and extrazonal primitive plant aggregation and a peculiar flora of tree and shrubbery plantings unique to the arid South-East of European Russia [1, 2].

Until now, systematic study of the mycobiota of the northern part of the Volga-Akhtuba floodplain (hereinafter VAF) has not been carried out, in the literature there exists fragmentary information about the species composition of the aphyllophorales mushrooms and their ecology features in the region [2-7].

At the same time, it should be emphasized that it is the northern part of the VAF within the Volgograd region that is the most representative part of the VAF with the maximum diversity of landscapes, forest communities and the corresponding flora and mycobiota.

The goal of research is to study the species composition and the ecology of the aphyllophorales mushrooms in the territory of the VAF within the Volgograd region.

\section{Materials and methods}

The mycobiota VAF research carried out according to classical methods [8-12]. The total number of samples collected was more than 1000.

Species determined using the works of domestic and foreign mycologists [13-22].

\footnotetext{
* Corresponding author: pipenko87@mail.ru
} 
Mushroom identification carried out on the basis of light microscopy («BIOLAM RFN$11 »$ ) using a standard set of reagents and electron microscope (scanning electron microscope Versa 3D) (figure 1). Samples tabulated based on the Microsoft Access 2007 application.
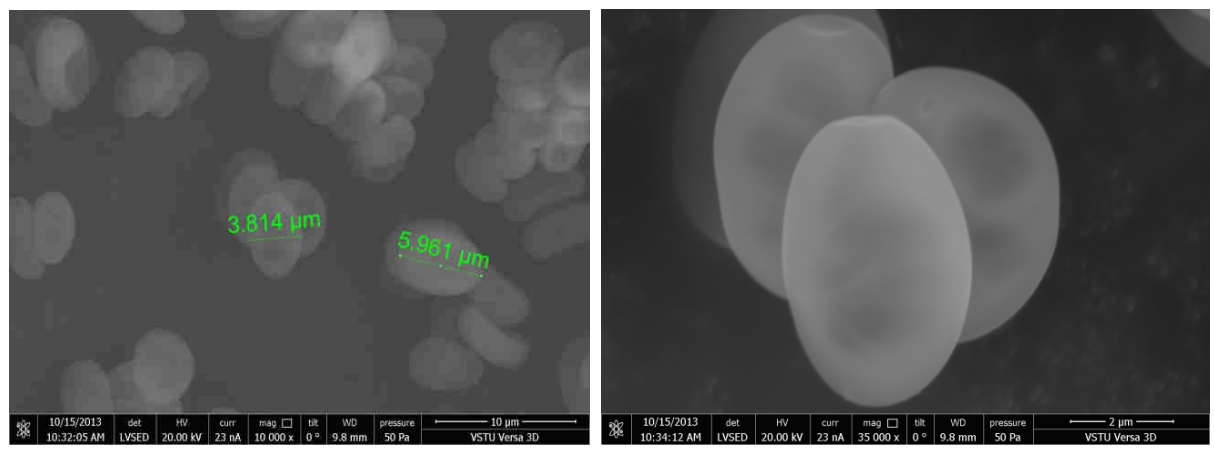

Fig. 1. Electron microscope image of mushroom spores Cerioporus squamosus (Huds.) Quél.

\section{Results and its discussion}

At present, in the territory of the VAF within the Volgograd region 170 aphyllophorales mushroom species were identified. According to the trophic affiliation, more than $90 \%$ of all the identified aphyllophorales mushroom belong to saprotrophs, which develop mainly on dead wood (deadwood and fallen trunks, stumps, fallen branches, etc.). Dead fallen wood is one of the most populated mushroom substrates, and some species found also on weakened trees (for example, species such as Bjerkandera adusta (Willd.) P. Karst., Cerioporus squamosus (Huds.) Quél., Schizophyllum commune Fr. etc.), dead trees (Porostereum spadiceum (Pers.) Hjortstam et Ryvarden, Vuilleminia comedens (Nees) Maire etc.) and on burned wood (Coniophora arida (Fr.) P. Karst., Ganoderma applanatum (Pers.) Pat., Phlebia rufa (Pers.) M. P. Christ. etc.).

For example, species such as Fomitiporia robusta (P. Karst.) Fiasson et Niemelä, Phaeolus schweinitzii (Fr.) Pat., Phellinus pomaceus (Pers.) Maire, Ph. tremulae (Bondartsev) Bondartsev et P. N. Borisov, Pseudoinonotus dryadeus (Pers.) T. Wagner et M. Fisch. parasitize on living trees and die after their withering away. But mushroom species found also that remain viable after the tree death (Chondrostereum purpureum (Pers.) Pouzar, Fistulina hepatica (Schaeff.) With., Ganoderma australe (Fr.) Pat., G. lucidum (Curtis) P. Karst. etc.).

Analyzing the substrate confinement revealed that the prevail number of mushroom is associated with the wood of only broad-leaved trees, the most rich in the species composition of the aphyllophorales mushroom Quercus robur L., Populus ssp. и Fraxinus lanceolata Borkh. (figure. 2). The most species specificity have Quercus robur, Pinus sylvestris и Fraxinus lanceolate. 30 stenotrophic mushroom were recorded on Quercus robur (for example, Abortiporus biennis (Bull.) Singer, Daedalea quercina (L.) Pers., etc.), on Pinus sylvestris - 14 stenotrophic species (Asterodon ferruginosus Pat., Auriscalpium vulgare Gray, etc.), on Fraxinus lanceolate - 11 stenotrophic plant (Ceraceomyces serpens (Tode) Ginns, Byssomerulius corium (Pers.) Parmasto, etc.). 


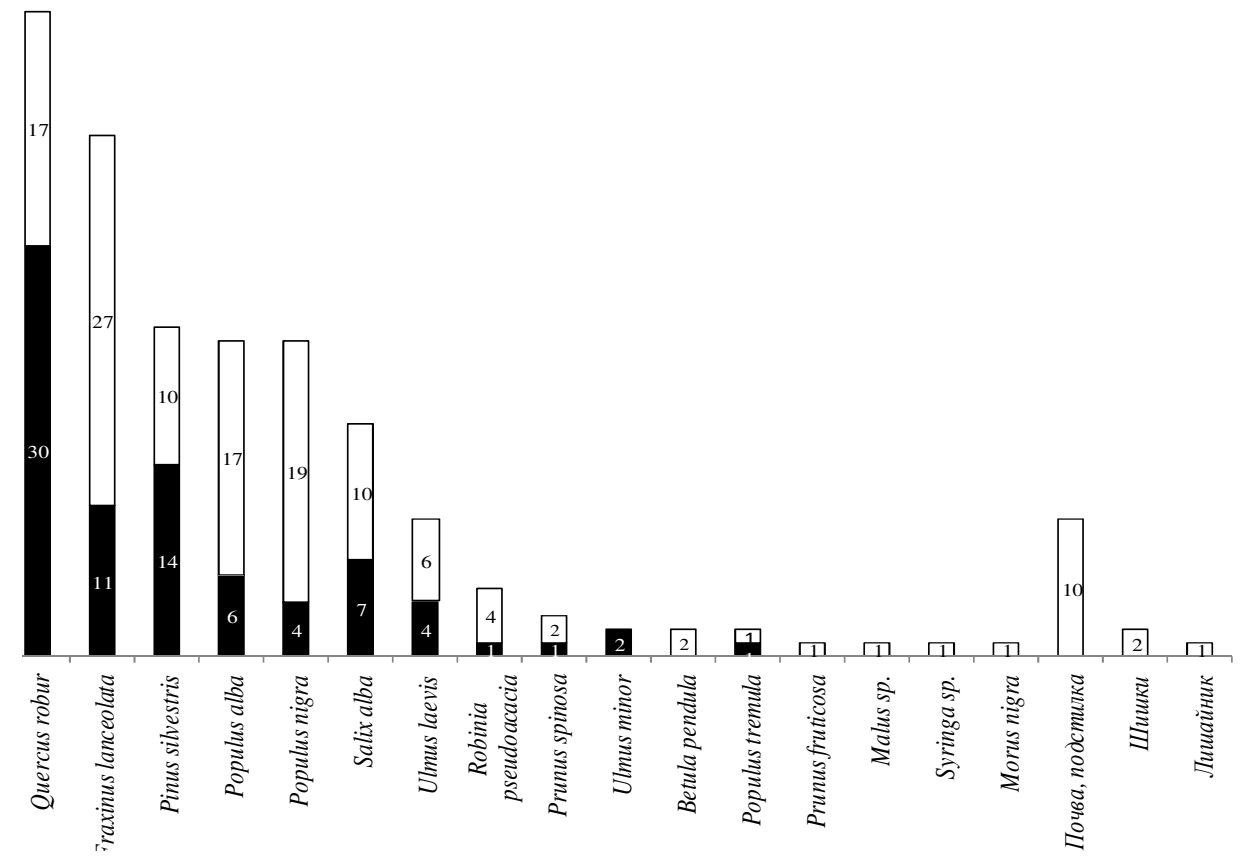

Fig. 2. Confinedness of aphyllophorales mushroom to a different substrate. Note. Above the columns are indicated the total number of mushroom species on this substrate. Black color marked stenotrophic species.

Mycobiota ecological analysis of the northern part of the VAF by moisture showed that mesophiles with a rather high number of xerophiles prevail, which is due to the climatic conditions of the dry-steppe plain zone [23-25].

\section{Conclusions}

The carried out researches showed that the biota of the aphyllophorales mushroom of the VAF is an original complex, different from the mycobiota of the Volgograd region. The natural park inhabits some mushroom species that determine the analyzed mycobiota originality and can be considered as including habitats of rare mushroom species (for example, Fistulina hepatica (Schaeff.) With., Ganoderma lucidum (Curtis) P. Karst.) and their complexes, which determines the need to give some of them environmental status [26].

I express my gratitude to Vlasenko V.A. (CSBG SB RAS), Sagalaev V.A. (VolSU) for the consultation, to Volobuev S.V. (BIN RAS) for the assistance in the identification of certain mushroom species, to Golovanova M.A. (VolSU) for the assistance in the collection of mushrooms and many others.

\section{References}

1. V.A. Sagalaev, Nat. park «VAF»: nat. resour. potent. 32-68 (2004)

2. V.V. Malychenko (sc.ed. and comp.), Volga-Akhtuba floodplain is a natural gift to mankind. Illustrated popular science essay on nature protection (Izdatel, Volgograd, 2006) 
3. Yu.A. Rebriev, V.A. Rusanov, T.S. Bulgakov, T.Yu. Svetasheva, I.V. Zmitrovich, E.S. Popov, Mycobiota of the arid territories of the south-west of Russia (SFU Publishing, Rostov-on-Don, 2012)

4. N.S. Kuragina, Fundam. res. (11), 211-213 (2013)

5. N.S. Kuragina, Vestnik NSU 12, 32-36 (2014)

6. N.S. Kuragina, Vestnik VSU (24), 111-116 (2014)

7. N.S. Kuragina, Mater. IV (XII) Int. Bot. Conf. Young Sci.. 211 (St. Petersburg, 2018)

8. A.S. Bondartsev, R.A. Zinger Guide to collecting higher basidiomycetes for scientific research (Academy of Sciences USSR Publishing, M.-Leningrad, 1950)

9. A.I. Tolmachev, Introduction to plant geography (LSU Publishing, Leningrad, 1974)

10. B.A. Yurtsev, Bot. J. 60, 69-83 (1975)

11. V.M. Schmidt, Statistical methods in comparative floristics (LSU Publishing, Leningrad, 1980)

12. V.M. Schmidt, Mathematical Methods in Botany (LSU Publishing, Leningrad, 1984)

13. M.A. Bondartseva, E.H. Parmasto, Families of the Hymenochaetales, Lachnocladiaceae, Coniophoraceae, Schizophyllaceae. Mushroom determinant of the USSR. Order Aphyllophorales (Science, Sankt-Peterburg,1986)

14. V.A. Mukhin, A field determinant of pungent mushroom (UFU Publishing, Yekaterinburg, 1997)

15. M.A. Bondartseva, The mushrooms determinant of Russia. Order Aphyllophorales (Science, Sankt-Peterburg, 1998)

16. E.H. Parmasto, The Determinant of Coral Mushrooms of the USSR (Science, M.Leningrad, 1965)

17. J. Eriksson, L. Ryvarden, The Corticiaceae of North Europe. HyphodermellaMycoacia (Fungiflora, Oslo, 1976)

18. L. Ryvarden, R.L. Gilbertson, European polypores. Part 1. Abortiporus-Lindtneria (Fungiflora, Oslo, 1993)

19. L. Ryvarden, R.L. Gilbertson, European polypores. Part 2. Meripilus-Tyromyces (Fungiflora, Oslo, 1994)

20. T. Niemelä, Polyporaceae of Finland and the adjoining territory of Russia (Publ. University of Helsinki, Helsinki, 2001)

21. T. Niemelä, Torikseened Soomes ja Eestis (Estonian-language edition of the Finnish original) (Publ. University of Helsinki, Helsinki, 2005)

22. V.M. Kotkova, T. Niemelä, I.A. Viner, D.S. Schigel, A.V. Kurakov, Polypore fungi: materials of the international course on ecology and taxonomy of lignicolous basidiomycetes in the Central Forest reserve (Helsinki University Printing House, Helsinki, 2015)

23. M.A. Safonov, Adv. curr. nat. Sci. 8, 62-65 (2015)

24. M.A. Safonov, Vestnik OSPU. Electron Sci. J. 3, 23-31 (2017)

25. A.-L. Ylisimiö, M. Mönkkönen, V. Halikainen, T. Ranta-Maunus, J. Kouki, For. Ecol. Manage. 373, 138-148 (2016)

26. V.A. Vlasenko, A.V. Vlasenko, Sci. Bull. BSU 41, 70-78 (2017) 